\title{
DNA barcoding of vouchered xylarium wood specimens of nine endangered Dalbergia species
}

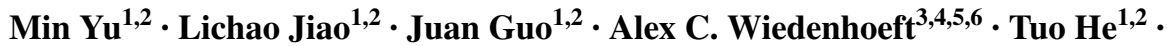 \\ Xiaomei Jiang ${ }^{1,2} \cdot$ Yafang Yin $^{1,2}(\mathbb{0}$
}

Received: 31 May 2017 / Accepted: 8 August 2017 / Published online: 19 August 2017

(C) Springer-Verlag GmbH Germany 2017

\begin{abstract}
Main conclusion ITS2+trnH-psbA was the best combination of DNA barcode to resolve the Dalbergia wood species studied. We demonstrate the feasibility of building a DNA barcode reference database using xylarium wood specimens.
\end{abstract}

The increase in illegal logging and timber trade of CITESlisted tropical species necessitates the development of unambiguous identification methods at the species level. For these methods to be fully functional and deployable for law enforcement, they must work using wood or wood products. DNA barcoding of wood has been promoted as a

Min Yu and Lichao Jiao contributed to the work equally and should be regarded as co-first authors.

Electronic supplementary material The online version of this article (doi:10.1007/s00425-017-2758-9) contains supplementary material, which is available to authorized users.

Yafang Yin

yafang@caf.ac.cn

1 Department of Wood Anatomy and Utilization, Chinese Research Institute of Wood Industry, Chinese Academy of Forestry, Beijing 100091, China

2 Wood Collections (WOODPEDIA), Chinese Academy of Forestry, Beijing 100091, China

3 Center for Wood Anatomy Research, USDA Forest Service, Forest Products Laboratory, Madison, WI 53726, USA

4 Department of Botany, University of Wisconsin, Madison, WI 53706, USA

5 Department of Forestry and Natural Resources, Purdue University, West Lafayette, IN 47907, USA

6 Ciências Biológicas (Botânica), Univesidade Estadual Paulista, Botucatu, São Paulo, Brazil promising tool for species identification; however, the main barrier to extensive application of DNA barcoding to wood is the lack of a comprehensive and reliable DNA reference library of barcodes from wood. In this study, xylarium wood specimens of nine Dalbergia species were selected from the Wood Collection of the Chinese Academy of Forestry and DNA was then extracted from them for further PCR amplification of eight potential DNA barcode sequences (ITS2, matK, trnL, trnH-psbA, trnV-trnM1, trnV-trnM2, trnC$\operatorname{pet} N$, and $\operatorname{trnS}$-trnG). The barcodes were tested singly and in combination for species-level discrimination ability by tree-based [neighbor-joining (NJ)] and distance-based (TaxonDNA) methods. We found that the discrimination ability of DNA barcodes in combination was higher than any single DNA marker among the Dalbergia species studied, with the best two-marker combination of ITS2+trnH-psbA analyzed with $\mathrm{NJ}$ trees performing the best ( $100 \%$ accuracy). These barcodes are relatively short regions $(<350 \mathrm{bp})$ and amplification reactions were performed with high success ( $\geq 90 \%)$ using wood as the source material, a necessary factor to apply DNA barcoding to timber trade. The present results demonstrate the feasibility of using vouchered xylarium specimens to build DNA barcoding reference databases.

Keywords DNA barcode reference database - ITS2 . trnH-psbA · CITES · Forensic wood identification · Illegal logging

\section{Introduction}

Deforestation represents a massive threat to global biodiversity, with illegal logging and the associated trade in illegally sourced wood products contributing significantly to continual forest loss. The consequences of these illegal 
activities are realized economically, socially, and ecologically (Reboredo 2013). Many countries have passed laws or regulations to combat illegal deforestation and trade by requiring some form of certification of lawful origin for wood and wood products (Lowe et al. 2016). Though various methods are used to identify wood along the forest products supply chain, current global identification capacity cannot meet demand. There are two reasons. (1) Traditional wood identification relies on diagnostic anatomical features observed by a trained expert, and this technology cannot identify wood samples to the species level because related species often have similar wood structure (Santos et al. 2013; Yu et al. 2016). (2) Phytochemical analysis (Mcclure et al. 2015), near infrared spectroscopy (Pastore et al. 2011; Bergo et al. 2016), real time time-of-flight mass spectrometry (Cody et al. 2012) for wood identification and isotopic analysis (Horacek et al. 2009; Kagawa and Leavitt 2010; Krüger et al. 2014) to determine provenance are growing but as-yet not widely deployable technologies. With progress in biotechnology, especially the application of DNA molecular marker technology in forensic medicine and archeology (Gould et al. 2010; Gismondi et al. 2012; Eurlings et al. 2013; Phong et al. 2014; Gismondi et al. 2015, 2016), another possible channel for reliably identifying wood and wood products and tracing their geographical origins is open (Nithaniyal et al. 2014; Schroeder et al. 2016).

DNA barcoding has become an effective tool for species identification of animals and medicinal plants (Zemlak et al. 2009; Zhang et al. 2015), the assessment of biodiversity (Lahaye et al. 2008; Ji et al. 2013; Yan et al. 2015) and monitoring the illegal trade of wildlife species (Baker 2008; Gathier et al. 2013; Schroeder et al. 2016), DNA barcoding has several advantages over traditional taxonomy (Hebert et al. 2003; Hajibabaei et al. 2007) or wood identification in that it is easy, fast and accurate to use, not affected by developmental stage and morphology (Chase et al. 2007; Lv et al. 2015), does not require years of specialized training, and the necessary lab equipment is essentially ubiquitous in molecular biology labs across the world. According to the Plant Working Group of Consortium for the Barcode of Life, an ideal DNA barcode should have a highly universal primer pair, show high success rates of PCR amplification and sequencing (Bolson et al. 2015), and provide maximal species discrimination at the species level (Hebert et al. 2003; Kress et al. 2005; Cowan et al. 2006; Hollingsworth et al. 2009). These guidelines implicitly assume high quality and quantity DNA, an assumption that is often violated when wood or wood products are the source of DNA, and only short DNA barcodes can reliably be amplified (Tang et al. 2011; Jiao et al. 2012, 2014, 2015; Yu et al. 2016).

In recent years, DNA methods to verify species identity and origin of internationally traded woods have attracted increasing interest to combat illegal logging (Lowe and
Cross 2011; Lowe et al. 2016). Several studies have shown the ability of barcoding to effectively discriminate important timber species, such as agarwood (Aquilaria) (Jiao et al. 2014; Lee et al. 2016), oak (Quercus) (Deguilloux and Petit 2004), and mahogany (Swietenia) (Degen et al. 2013). More recent studies have included Dalbergia species, focusing on species identification in Southeast Asia and Madagascar (Hartvig et al. 2015; Hassold et al. 2016; Yu et al. 2016).

Dalbergia L.f., a pantropical genus of 304 species in the Leguminosae, grow as shrubs, lianas and trees (The Plant List 2013). The tree species of Dalbergia are often economically important for their quality timber (Bhagwat et al. 2015). Illegal and excessive logging have led to damage of wild Dalbergia resources: 54 species of Dalbergia (including 48 species in populations of Madagascar) were listed by the Convention on International Trade in Endangered Species of Wild Fauna and Flora (CITES) by 2013; 86 Dalbergia species were included on the Red List by the International Union for Conservation of Nature (IUCN) (The IUCN Red List of Threatened Species 2016); at the 17th Meeting of the Conference of the Parties to CITES in 2016, all the Dalbergia species worldwide were listed in Appendix II, and this listing took effect in January 2017. Despite global CITES protection for the genus, the commercial market preferentially selects individual species that may have protection at national or regional levels. For example, in 1999 the Chinese Government protected Dalbergia odorifera (The State Council of the People's Republic of China 1999); it is prized in Chinese traditional furniture and traditional medicines, is the source of more than 40 individual flavonoids, quinones, and other phenols, and is reported to have various medicinal properties (Ogata et al. 1990; Wang et al. 2000; Tao and Wang 2010).

Currently, the main barrier to extensive application of DNA barcoding is the lack of a reliable DNA reference library (Hartvig et al. 2015; Hassold et al. 2016; Lowe et al. 2016). Previous attempts using molecular markers to identify different Dalbergia species have been carried out, but the prerequisite of a large sampling of wood tissues and effective DNA barcodes to serve as a reference database has often limited its practical application for accurate identification (Bhagwat et al. 2015; Hartvig et al. 2015; Hassold et al. 2016; Yu et al. 2016). Moreover, some potential DNA barcode sequences (Ribeiro et al. 2011), namely trnV-trnM,

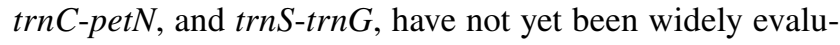
ated for species discrimination in Dalbergia woods.

To achieve species-level identification of some commercially important Dalbergia, we chose to develop DNA barcodes from botanically verified wood xylarium specimens. DNA barcoding of wood is not necessarily as simple or direct as DNA barcoding of other plant parts that can be collected and analyzed in the living state, so the use of xylarium specimens is critical to ensure that the barcodes 
developed will work for wood and wood products in trade. Xylaria provide the botanical foundation for forensic work in support of the timber trade, law enforcement, archeology and conservation and restoration of architectural wood heritage, as well as serving as repositories of DNA (Jiao et al. 2014, 2015), plant chemistry, and isotopic signatures (Wiedenhoeft 2014). Like herbaria (Puillandre et al. 2012; Xu et al. 2015), xylaria may have specimens from extirpated populations, concentrate specimens from across the world in one place, and for wood forensics also represent the relevant botanical material (wood) in need of identification.

In this study, we selected xylarium specimens of nine Dalbergia species and evaluated eight candidate DNA markers (ITS2, matK, trnL, trnH-psbA, trnV-trnM1, trnV-trnM2, $\operatorname{trn} C$-pet $N$, and $\operatorname{trn} S$-trnG) for their efficacy at species-level separation. Specifically, our objectives were to: (1) evaluate the amplification success of a range of the eight candidate barcodes from wood specimens; (2) compare the effect of tree-based [neighbor-joining (NJ)] and distance-based (TaxonDNA) methods on Dalbergia species resolution; (3) evaluate the species discrimination power of the single barcodes and their combinations for the genus Dalbergia to identify the most efficient set of barcodes for DNA barcoding of Dalbergia wood and wood products.

\section{Materials and methods}

\section{Specimen sampling}

All wood specimens were taken from the xylarium (wood collections) of the Chinese Academy of Forestry (WOODPEDIA), the largest wood collection in China. A total of 50 specimens of 9 species of Dalbergia were sampled.
Four types of specimens, i.e., heartwood, sapwood, twig, and silica gel-dried leaf were collected in this study. 3-9 individuals per species were sampled. Detailed information about sample species, sample identification, voucher identification, and type of sample are shown in supplementary material Table S1.

\section{Primer design}

101 Dalbergia DNA sequences, namely internal transcribed spacer 2 (ITS2), trnV-trnM, trnC-pet $N$, and trnS-trnG, were downloaded from NCBI (Supplementary material Table S2). Sequences were aligned using MEGA 5.05 (The Biodesign Institute, Tempe, AZ, USA). Universal primers were manually selected from conserved regions adjacent to the selected variable regions using Primer Premier 5 (Premier Biosoft International, Palo Alto, CA, USA). We designed two pairs of primers for amplifying the trn $V$-trnM different variable region, and were named trnV-trnM1 and trnV-trnM2 separately. In addition, the primers for amplifying three other chloroplast regions, namely matK, $\operatorname{trnL}$, and $\operatorname{trnH}$-psbA, were employed in this study (as in Yu et al. 2016). Details are listed in Table 1.

\section{DNA extraction, amplification and sequencing}

All xylarium specimens, including heartwood, sapwood, and twigs, were washed with $75 \%$ ethanol before removing the surface tissue with a sterile scalpel blade. Wood shavings were cut with a sterile scalpel blade from wood samples for freeze grinding. About $500 \mathrm{mg}$ of wood shavings were placed in a grinding vial together with a stainless steel impactor, frozen in liquid nitrogen for $2 \mathrm{~min}$, and then disrupted into fine powder using an EFM Freezer

Table 1 Primer pairs of DNA region and reaction conditions applied for the PCR amplification tests in this study

\begin{tabular}{|c|c|c|c|c|}
\hline DNA marker & Name of primers & Primer sequences $\left(5^{\prime}-3^{\prime}\right)$ & PCR conditions & References \\
\hline ITS2 & $\begin{array}{l}\text { ITS2-F } \\
\text { ITS2-R }\end{array}$ & $\begin{array}{l}\text { ATGCGATACTTGGTGTGA TAG } \\
\text { CCCCGCCTGAACCTGA }\end{array}$ & $\begin{array}{l}94^{\circ} \mathrm{C} 5 \mathrm{~min} ; 94{ }^{\circ} \mathrm{C} 30 \mathrm{~s}, 52^{\circ} \mathrm{C} 45 \mathrm{~s}, 72^{\circ} \mathrm{C} 45 \mathrm{~s} \text {, } \\
40 \text { cycles; } 72{ }^{\circ} \mathrm{C} 10 \mathrm{~min}\end{array}$ & This study \\
\hline$m a t K$ & $\begin{array}{l}\text { matK-F } \\
\text { matK-R }\end{array}$ & $\begin{array}{l}\text { GTCTTCGATACTGGGTGAA } \\
\text { GATCGTTCCAGGTTGAGA }\end{array}$ & $\begin{array}{l}94{ }^{\circ} \mathrm{C} 5 \mathrm{~min} ; 94^{\circ} \mathrm{C} 30 \mathrm{~s}, 49^{\circ} \mathrm{C} 45 \mathrm{~s}, 72{ }^{\circ} \mathrm{C} 45 \mathrm{~s} \text {, } \\
40 \text { cycles; } 72{ }^{\circ} \mathrm{C} 10 \mathrm{~min}\end{array}$ & Jiao et al. unpublished \\
\hline $\operatorname{trn} L$ & $\begin{array}{l}\operatorname{trnL}-\mathrm{F} \\
\operatorname{trnL}-\mathrm{R}\end{array}$ & $\begin{array}{l}\text { CTGAAAGTAAAGAAAAGT } \\
\text { TATGATGGAGTGAATGAT }\end{array}$ & $\begin{array}{l}94{ }^{\circ} \mathrm{C} 5 \mathrm{~min} ; 94^{\circ} \mathrm{C} 30 \mathrm{~s}, 40^{\circ} \mathrm{C} 45 \mathrm{~s}, 72^{\circ} \mathrm{C} 45 \mathrm{~s} \text {, } \\
40 \text { cycles; } 72{ }^{\circ} \mathrm{C} 10 \mathrm{~min}\end{array}$ & Jiao et al. unpublished \\
\hline $\operatorname{trnH}-p s b A$ & $\begin{array}{l}\text { TP-F } \\
\text { TP-R }\end{array}$ & $\begin{array}{l}\text { CTTCCCTCTAGACCTAGCTTCG } \\
\text { TTGGCTACATCCGCCCTT }\end{array}$ & $\begin{array}{l}94{ }^{\circ} \mathrm{C} 5 \mathrm{~min} ; 94{ }^{\circ} \mathrm{C} 30 \mathrm{~s}, 61^{\circ} \mathrm{C} 45 \mathrm{~s}, 72^{\circ} \mathrm{C} 45 \mathrm{~s} \text {, } \\
40 \text { cycles; } 72{ }^{\circ} \mathrm{C} 10 \mathrm{~min}\end{array}$ & Yu et al. (2016) \\
\hline $\operatorname{trn} V$-trnM 1 & $\begin{array}{l}\text { TVM1-F } \\
\text { TVM1-R }\end{array}$ & $\begin{array}{l}\text { GATGATTCCCTGTGC } \\
\text { AACAATAGCCTGACAAA }\end{array}$ & $\begin{array}{l}94{ }^{\circ} \mathrm{C} 5 \mathrm{~min} ; 94^{\circ} \mathrm{C} 30 \mathrm{~s}, 53{ }^{\circ} \mathrm{C} 45 \mathrm{~s}, 72^{\circ} \mathrm{C} 45 \mathrm{~s} \text {, } \\
40 \text { cycles; } 72{ }^{\circ} \mathrm{C} 10 \mathrm{~min}\end{array}$ & This study \\
\hline $\operatorname{trn} V$-trnM2 & $\begin{array}{l}\text { TVM2-F } \\
\text { TVM2-R }\end{array}$ & $\begin{array}{l}\text { TTGATGTCTAAACCCTT } \\
\text { CAATACCAACGCAAT }\end{array}$ & $\begin{array}{l}94{ }^{\circ} \mathrm{C} 5 \mathrm{~min} ; 94^{\circ} \mathrm{C} 30 \mathrm{~s}, 51^{\circ} \mathrm{C} 45 \mathrm{~s}, 72^{\circ} \mathrm{C} 45 \mathrm{~s} \text {, } \\
40 \text { cycles; } 72{ }^{\circ} \mathrm{C} 10 \mathrm{~min}\end{array}$ & This study \\
\hline $\operatorname{trnC}$-petN & $\begin{array}{l}\text { TCN-F } \\
\text { TCN-R }\end{array}$ & $\begin{array}{l}\text { TCTGGCAGTTATTC } \\
\text { AAAGGGATTCTGTGC }\end{array}$ & $\begin{array}{l}94{ }^{\circ} \mathrm{C} 5 \mathrm{~min} ; 94{ }^{\circ} \mathrm{C} 30 \mathrm{~s}, 52^{\circ} \mathrm{C} 45 \mathrm{~s}, 72^{\circ} \mathrm{C} 45 \mathrm{~s} \text {, } \\
40 \text { cycles; } 72{ }^{\circ} \mathrm{C} 10 \mathrm{~min}\end{array}$ & This study \\
\hline trnS-trnG & $\begin{array}{l}\text { TSG-F } \\
\text { TSG-R }\end{array}$ & $\begin{array}{l}\text { AGTAGGGCTTGAAAA } \\
\text { GGCGAATCTAAGTTT }\end{array}$ & $\begin{array}{l}94{ }^{\circ} \mathrm{C} 5 \mathrm{~min} ; 94^{\circ} \mathrm{C} 30 \mathrm{~s}, 50{ }^{\circ} \mathrm{C} 45 \mathrm{~s}, 72^{\circ} \mathrm{C} 45 \mathrm{~s} \text {, } \\
40 \text { cycles; } 72^{\circ} \mathrm{C} 10 \mathrm{~min}\end{array}$ & This study \\
\hline
\end{tabular}


Mill 6770 (SPEX SamplePrep, Metuchen, NJ, USA) for $4 \mathrm{~min}$. The grinding vial and stainless steel impactor were washed several times between specimens with DNAZap ${ }^{\mathrm{TM}}$ Solutions (Thermo Fisher Scientific Inc., Waltham, USA) and distilled water to avoid cross contamination with other samples.

Genomic DNA was extracted from silica gel-dried leaves using the DNeasy Plant Mini Kit (Qiagen, Hilden, Germany) following the manufacturer's recommendations. For wood samples, a slight modification was applied according to Yu et al. (2016). Concentrations of DNA were quantified using a NanoDrop 8000 spectrophotometer (Thermo Scientific, Waltham, MA, USA) and DNA integrity was checked on $1.0 \%$ agarose gels (TaKaRa, Dalian, China). Finally, the DNA extracts were purified twice with a High Pure PCR Template Preparation Kit (Roche, Mannheim, Germany) before used as templates for PCR.

Eight plant DNA barcodes were amplified, i.e., the chloroplast DNA matK and $t r n L$, the chloroplast intergenic spacer (of loci trnV-trnM1, trnV-trnM2, trnC-pet N, trnH$p s b A$, and $\operatorname{trn} S$-trnG) and the nuclear DNA region ITS2. PCR amplification was performed in a $25 \mu 1$ reaction with

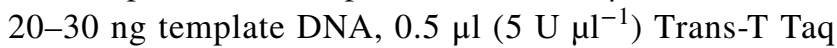
DNA polymerase (TransGen Biotech, Beijing, China), $2 \mu \mathrm{l}$ dNTP mixture ( $2.5 \mathrm{mM}$ of each dNTP), $3.5 \mu \mathrm{l} 10 \times$ Trans$\mathrm{T}$ Taq Buffer (TransGen Biotech, Beijing, China), and $1 \mu \mathrm{l}(20 \mu \mathrm{M})$ forward and reverse primer, respectively. The amplification was conducted in a Veriti 96-Well Thermal Cycler (Applied Biosystems, Foster City, CA, USA). PCR Primers and PCR cycling conditions used in this study are provided in Table 1. PCR products were purified with a SanPrep Column DNA Gel Extraction Kit (Sangon Biotech, Shanghai, China).

The purified PCR products were cloned with the pEASYT1 Simple Cloning Kit (TransGen Biotech, Beijing, China), according to the manual provided by the supplier. A total of ten clones were randomly selected and cultured. We further screened positive clones through PCR amplification and agarose gel electrophoresis. Five qualified positive clones from each sample were chosen to be sequenced. The nucleotide sequences of the cloned barcode DNAs were directly determined from the purified plasmid using M13 forward and reverse primers, by means of an ABI PRISM 3730xl DNA Sequencer (Applied Biosystems, Foster City, CA, USA) and BigDye Terminator v3.1 Cycle Sequencing Kit (Applied Biosystems, Foster City, CA, USA). For cycle sequencing a $10 \mu \mathrm{l}$ reaction volume including $1 \mu \mathrm{l}$ of either the forward or the reverse primer $(10 \mu \mathrm{M}), 0.5 \mu \mathrm{l}$ of BigDye Terminator v3.1 Ready Reaction mix, $1.75 \mu \mathrm{l}$ of sequencing buffer, $4 \mu \mathrm{l}$ of amplified purified product, and $2.75 \mu \mathrm{l}$ of $\mathrm{dd}_{2} \mathrm{O}$ was used. Cycle sequencing parameters consisted of an initial $96{ }^{\circ} \mathrm{C}$ for $1 \mathrm{~min}$, followed by 30 cycles $96^{\circ} \mathrm{C}$ for $10 \mathrm{~s}, 50{ }^{\circ} \mathrm{C}$ for $5 \mathrm{~s}$, and $60^{\circ} \mathrm{C}$ for $4 \mathrm{~min}$, finally $60^{\circ} \mathrm{C}$ for $5 \mathrm{~min}$.

\section{Data analysis}

Bidirectional sequences were assembled and edited using EditSeq program in the Lasergene Suite 7 (DNASTAR, Madison, WI, USA), and trimmed for primer sequences on both ends (Hartvig et al. 2015). The edited sequences were aligned using Clustal X 1.83 (UCD Conway Institute, Dublin, Ireland). The alignments were then adjusted manually by means of BioEdit software (http://www.mbio.ncsu.edu. proxy 1.lib.uwo.ca/BioEdit/bioedit.html). All variable sites were rechecked on the original trace files for final confirmation (Gao et al. 2017). Of the 50 specimens used in this study, one sample was previously sequenced for the $\operatorname{trn} L$ barcode region (Table S1).To increase the species identification accuracy of the eight potential barcodes and to serve as a positive control that wood DNA sequences matched those of other tissues, sequence data of Dalbergia deposited in GenBank were used. According to the workflow for data processing and analysis of DNA barcoding reported by Pang et al. (2012), low-quality sequences with more than $1 \%$ nucleotides being "Ns" were removed and the longest and shortest $1 \%$ sequences were treated as outliers and excluded. Thus, five low-quality and/or short sequences were removed, the names and accession numbers of which are listed in supplementary material Table S2. To ensure that our DNA barcodes could be applied to wood and wood products from trade, barcodes with PCR success rate below 70\% (on a specimen basis) were excluded from further analysis, leaving five of the eight original barcodes.

Intraspecific and interspecific genetic distances were calculated using the Kimura two-parameter (K2P) model by MEGA 5.05 (Kumar et al. 2008; Bhagwat et al. 2015). The relative distribution of the pairwise intraspecific and interspecific distances were estimated using the "pairwise summary" function in TaxonDNA (National University of Singapore, Singapore) under the K2P distances model for the eight single barcodes and all combinations of the barcodes not pruned for failure to amplify reliably. To evaluate species discrimination success, unrooted $\mathrm{NJ}$ trees were constructed in MEGA 5.05 with pairwise deletion and the P-distance model according to the published protocols for species-level discrimination (Tamura et al. 2011; Yan et al. 2015; Hartvig et al. 2015; Gao et al. 2017). The bootstrap supporting option was set to 1000 random addition replicates to determine statistical support for the clades. Only when all the conspecific individuals were clustered in a single clade and at least one specimen in each clade was derived from a botanically vouchered collection was it considered a successful species discrimination. The "best match" and "best close match" functions in the TaxonDNA software were used to test all eight single barcodes and all combinations of the five barcodes under the $\mathrm{K} 2 \mathrm{P}$ corrected distance model (Meier et al. 2006; Bolson et al. 2015; Hassold et al. 2016). 


\section{Results}

\section{Amplification, sequencing success and marker features}

Average DNA quantities following total genomic DNA isolation from sapwood, heartwood, and twigs were 18.9, 10.6 and $28.8 \mathrm{ng} \mathrm{mg}^{-1}$, respectively. The amplification reactions were performed with high success $(>90 \%)$ for $\operatorname{trn} V$-trnM1, trnH-psbA, and ITS2, whereas trnC-petN demonstrated lower PCR amplification efficiency, successful in only $44 \%$ of the samples. The success rate for bidirectional sequencing of PCR products was $100 \%$ for all eight loci (Table 2). Our work generated a database of 302 new sequences in Dalbergia, all of which have been deposited in GenBank. Their accession numbers are listed in supplementary material Table S1 (including 45 ITS2, $34 \mathrm{matK}, 41 \mathrm{trnL}, 48 \mathrm{trnH}$ psbA, 49 trnV-trnM1, 37 trnV-trnM2, 22 trnC-petN, and 26 trnS-trn $G$ sequences).

Based on multiple alignments of all sequences for the eight loci, the aligned DNA sequence lengths ranged from $277 \mathrm{bp}(\operatorname{trn} V$-trnM2) to $521 \mathrm{bp}(\operatorname{trnC}$-pet $N)$. Due to the presence of indels, the biggest length variation was detected in trnC-petN (478-511 bp) stemming from 45 indels (Table 2). The information of intraspecific and interspecific sequence divergence for each barcode sequence are presented in the supplementary materials Table S3. ITS2 provided the highest proportion of informative sites with a short aligned sequence length $(80 / 348 \mathrm{bp})$, followed by trnS-trnG (34/335 bp), trnV-trnM1 (28/357 bp), trnC-petN (38/521 bp), trnH-psbA (23/334 bp), trnL (20/314 bp) and matK (17/467 bp), with trnV-trnM2 showing the lowest values $(7 / 277 \mathrm{bp})$.

\section{DNA barcoding gap assessment}

An ideal DNA barcode should have low intraspecific variation, high interspecific divergence, and the minimum interspecific divergence should be greater than the maximum intraspecific variation (Zhang et al. 2015). Pairwise intraspecific distances in the eight loci ranged from 0.011 to 0.090 , while the pairwise interspecific distances ranged from 0.022 to 0.151 . The results indicated that ITS2 exhibits the highest intraspecific and interspecific genetic variation, whereas $m a t K$ possess the lowest intraspecific and interspecific genetic variation. The pairwise intraspecific distances in combined barcodes ranged from 0.010 to 0.136 and pairwise interspecific distances in combined barcodes ranged from 0.029 to 1.853 . Among combined barcodes, trnVtrnM1+trnH-psbA+trnL had the highest intraspecific and interspecific genetic variation, whereas the lowest intraspecific and interspecific genetic variation belonged to $t r n V$ trnM1+trnV-trnM2 (Table 3). We did not find any distinct barcoding gap between intraspecific variation and interspecific divergence in the distributions of the single barcodes or multi-locus barcodes (Supplementary material Fig. S1). Despite this, there is a defined range where the intraspecific variation is considerably lower than the distribution of the interspecific divergence in single and combined barcodes.

\section{Species discrimination}

TaxonDNA was used to analyze all sequences generated in this study as well as those downloaded from GenBank (Supplementary material Tables S1, S2). Both the "best match" and "best close match" methods provided the similar species discrimination success for the single barcodes and multi-locus barcodes. Moreover, comparing the results of the "best match" and "best close match" analysis, the former always showed higher or equal individual identification rates than the latter (Fig. 1). The results of the "best close match" analysis for single regions revealed ITS2 as the best at species identification (97.5\%), followed by $\operatorname{trnL}(96.7 \%)$, trnC-petN (91.3\%), matK (65.9\%), trnH-psbA (63.6\%), trnVtrnM2 (42.5\%), trnV-trnM1 (42.3\%), and trnS-trnG (25.9\%). Correct identification rates of all barcode combinations were higher than $80 \%$. Moreover, any combination of the barcodes

Table 2 The characteristics of the eight DNA barcode loci

\begin{tabular}{|c|c|c|c|c|c|c|c|c|}
\hline DNA marker & $\begin{array}{l}\text { PCR success } \\
\text { rate }(\%)\end{array}$ & $\begin{array}{l}\text { Sequencing suc- } \\
\text { cess rate }(\%)\end{array}$ & $\begin{array}{l}\text { Sequence } \\
\text { length (bp) }\end{array}$ & $\begin{array}{l}\text { Aligned } \\
\text { sequence length } \\
\text { (bp) }\end{array}$ & $\mathrm{G}+\mathrm{C}$ ratio $(\%)$ & $\begin{array}{l}\text { No. of vari- } \\
\text { able sites }\end{array}$ & $\begin{array}{l}\text { No. of } \\
\text { informative } \\
\text { sites }\end{array}$ & $\begin{array}{l}\text { Indel } \\
\text { length } \\
\text { (bp) }\end{array}$ \\
\hline $\operatorname{trn} V$-trnM1 & 98 & 100 & $348-357$ & 357 & $34.7-36.3$ & 29 & 28 & 9 \\
\hline trnH-psbA & 96 & 100 & $318-328$ & 334 & $31.0-32.5$ & 25 & 23 & 28 \\
\hline ITS2 & 90 & 100 & $343-346$ & 348 & $61.2-66.2$ & 90 & 80 & 7 \\
\hline $\operatorname{trn} L$ & 82 & 100 & $301-310$ & 314 & $30.3-32.2$ & 28 & 20 & 12 \\
\hline $\operatorname{trn} V$-trnM2 & 74 & 100 & $270-277$ & 277 & $34.8-36.3$ & 15 & 7 & 7 \\
\hline$m a t K$ & 68 & 100 & $465-467$ & 467 & $30.4-32.1$ & 24 & 17 & 2 \\
\hline $\operatorname{trnS}$-trnG & 52 & 100 & $304-325$ & 335 & $18.8-21.1$ & 35 & 34 & 39 \\
\hline trnC-petN & 44 & 100 & $478-511$ & 521 & $25.4-27.4$ & 39 & 38 & 45 \\
\hline
\end{tabular}


Table 3 Genetic distance generated using Kimura two-parameter model analysis for the candidate barcode loci and their combinations

\begin{tabular}{|c|c|c|c|c|c|c|}
\hline \multirow[t]{2}{*}{ Single and combined barcode loci } & \multicolumn{3}{|c|}{ Intraspecific distance } & \multicolumn{3}{|c|}{ Interspecific distance } \\
\hline & Minimum & Maximum & Mean & Minimum & Maximum & Mean \\
\hline ITS2 & 0.000 & 0.090 & 0.012 & 0.000 & 0.151 & 0.072 \\
\hline matK & 0.000 & 0.011 & 0.001 & 0.000 & 0.022 & 0.011 \\
\hline $\operatorname{trn} L$ & 0.000 & 0.013 & 0.001 & 0.003 & 0.035 & 0.020 \\
\hline $\operatorname{trnH}-p s b A$ & 0.000 & 0.008 & 0.001 & 0.000 & 0.042 & 0.017 \\
\hline $\operatorname{trn} V$-trnM1 & 0.000 & 0.003 & 0.000 & 0.000 & 0.051 & 0.024 \\
\hline $\operatorname{trn} V$-trnM2 & 0.000 & 0.023 & 0.003 & 0.000 & 0.034 & 0.011 \\
\hline $\operatorname{trnC}$-pet $N$ & 0.000 & 0.004 & 0.001 & 0.004 & 0.051 & 0.031 \\
\hline $\operatorname{trnS}$-trnG & 0.000 & 0.003 & 0.001 & 0.000 & 0.084 & 0.048 \\
\hline ITS $2+\operatorname{trn} L$ & 0.000 & 0.009 & 0.002 & 0.000 & 0.094 & 0.050 \\
\hline ITS2+trnH-psbA & 0.000 & 0.014 & 0.002 & 0.003 & 0.098 & 0.050 \\
\hline ITS2+trnV-trnM1 & 0.000 & 0.009 & 0.001 & 0.000 & 0.096 & 0.046 \\
\hline ITS2+trnV-trnM2 & 0.000 & 0.010 & 0.003 & 0.005 & 0.089 & 0.046 \\
\hline $\operatorname{trnH}-p s b A+t r n L$ & 0.000 & 0.010 & 0.002 & 0.000 & 0.046 & 0.027 \\
\hline trnH-psbA+trnV-trnM1 & 0.000 & 0.005 & 0.001 & 0.002 & 0.045 & 0.023 \\
\hline trnH-psbA+trnV-trnM2 & 0.000 & 0.010 & 0.003 & 0.003 & 0.035 & 0.020 \\
\hline $\operatorname{trn} V$-trnM1+trnL & 0.000 & 0.009 & 0.001 & 0.005 & 0.046 & 0.024 \\
\hline trnV-trnM1+trnV-trnM2 & 0.000 & 0.010 & 0.002 & 0.002 & 0.029 & 0.015 \\
\hline $\operatorname{trn} L+\operatorname{trn} V-\operatorname{trn} M 2$ & 0.000 & 0.021 & 0.003 & 0.003 & 0.034 & 0.019 \\
\hline ITS2+trnH-psbA+trnV-trnM1 & 0.000 & 0.009 & 0.001 & 0.005 & 0.076 & 0.040 \\
\hline ITS $2+t r n L+t r n V-t r n M 2$ & 0.000 & 0.013 & 0.003 & 0.009 & 0.066 & 0.038 \\
\hline $\operatorname{trn} V$-trnM1+trnH-psbA+trnL & 0.000 & 0.136 & 0.017 & 0.068 & 1.853 & 1.077 \\
\hline trnV-trnM1+trnH-psbA+trnV-trnM2 & 0.000 & 0.006 & 0.002 & 0.005 & 0.033 & 0.020 \\
\hline $\operatorname{trn} V$-trnM $1+\mathrm{ITS} 2+\operatorname{trn} L$ & 0.000 & 0.006 & 0.001 & 0.007 & 0.075 & 0.040 \\
\hline trnV-trnM1+ITS2+trnV-trnM2 & 0.000 & 0.006 & 0.002 & 0.005 & 0.071 & 0.036 \\
\hline $\operatorname{trn} V$-trnM $1+$ trnL+trnV-trnM2 & 0.000 & 0.013 & 0.002 & 0.004 & 0.035 & 0.020 \\
\hline $\operatorname{trnH}-p s b A+\mathrm{ITS} 2+\operatorname{trn} L$ & 0.000 & 0.009 & 0.002 & 0.010 & 0.074 & 0.043 \\
\hline trnH-psbA+ITS2+trnV-trnM2 & 0.000 & 0.010 & 0.003 & 0.010 & 0.069 & 0.040 \\
\hline trnH-psbA+trnL+trnV-trnM2 & 0.000 & 0.013 & 0.003 & 0.009 & 0.035 & 0.022 \\
\hline trnV-trnM1+trnH-psbA+ITS2+trnL & 0.000 & 0.007 & 0.001 & 0.008 & 0.064 & 0.037 \\
\hline $\operatorname{trn} V$-trnM1+ITS2+trnL+trnV-trnM2 & 0.000 & 0.009 & 0.002 & 0.006 & 0.059 & 0.033 \\
\hline trnV-trnM1+trnH-psbA+trnL+trnV-trnM2 & 0.000 & 0.010 & 0.002 & 0.006 & 0.031 & 0.021 \\
\hline $\operatorname{trn} V$-trnM1+trnH-psbA+ITS2+trnV-trnM2 & 0.000 & 0.007 & 0.002 & 0.007 & 0.061 & 0.034 \\
\hline trnH-psbA+ITS2+trnL+trnV-trnM2 & 0.000 & 0.010 & 0.003 & 0.010 & 0.059 & 0.036 \\
\hline $\operatorname{trn} V$-trnM1+trnH-psbA+ITS2+trnL+trnV-trnM2 & 0.000 & 0.008 & 0.002 & 0.008 & 0.053 & 0.032 \\
\hline
\end{tabular}

obviously increased species discrimination rates compared with a single marker. The results shows that ten barcode combinations, ITS2+trnL, ITS2+trnH-psbA, trnH-psbA+trnL, trnH-psbA+trnV-trnM1, trnV-trnM1+trnL, ITS2+trnHpsbA+trnV-trnM1, trnV-trnM1+trnH-psbA+trnL, trnV$\operatorname{trn} M 1+\mathrm{ITS} 2+\operatorname{trn} L$, trnH-psbA+ITS2+trnL, and trnVtrnM $1+$ trn $H-p s b A+\mathrm{ITS} 2+\operatorname{trn} L$, could provide higher success rate $(\geq 95 \%)$ compared with other barcode combinations based on the "best close match" analysis. The $\operatorname{trn} V$ trnM1+trnV-trnM2 combination exhibited the lowest performance for correct identification and the largest proportion of no match. Combinations of more than two markers did not significantly improve the identification rates.
A NJ tree for the best-performing two-marker combination of ITS2+trnH-psbA is shown for identifying these Dalbergia species (Fig. 2). NJ trees based on the eight single barcodes and the other analyzed combinations are available in the supplementary material (Supplementary material Fig. S2, Table S4). Species discrimination using only one locus was insufficient to provide an accurate resolution among the $\mathrm{Dal}$ bergia species studied here. When combining two to five barcodes, the highest discrimination rate $(100 \%)$ was achieved by ITS2+trnH-psbA (Fig. 2), trnH-psbA+trnL, trnV-trnM1+trnL, ITS2+trnL, trnV-trnM1+ITS2+trnL, trnH-psbA+ITS2+trnL, ITS2+trnH-psbA+trnV-trnM1, trnV-trnM1+trnL+trnH-psbA, and trnV-trnM1+trnH-psbA+ITS2+trnL (Fig. S2). Based on 


\section{Correct VIIA Ambiguous}

\section{a}

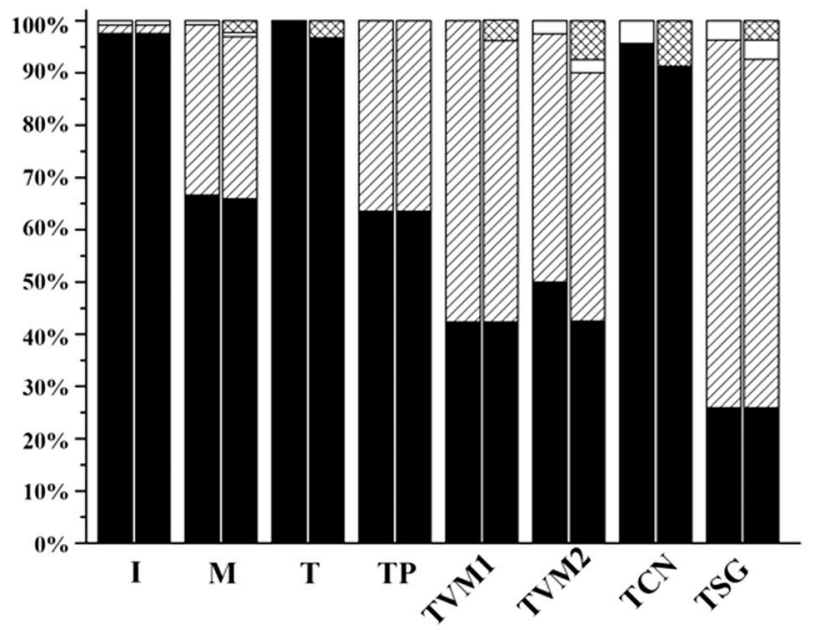

c

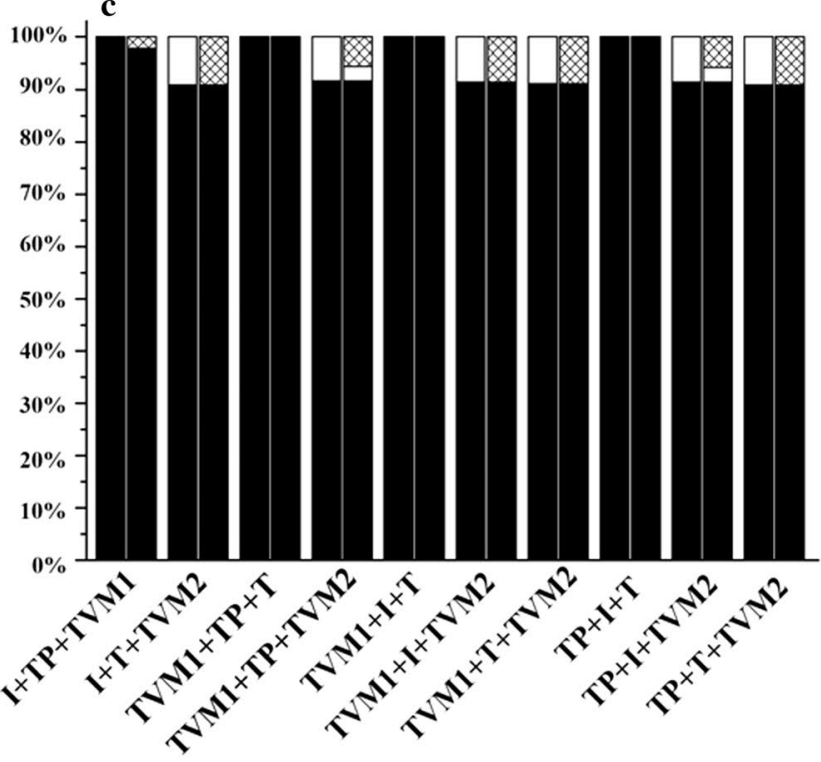

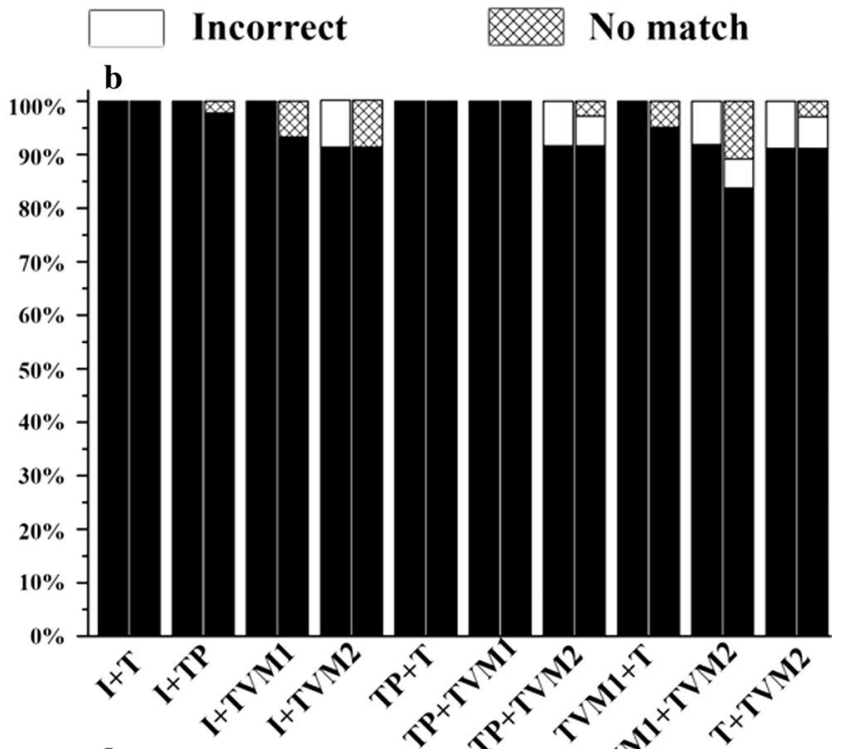

d

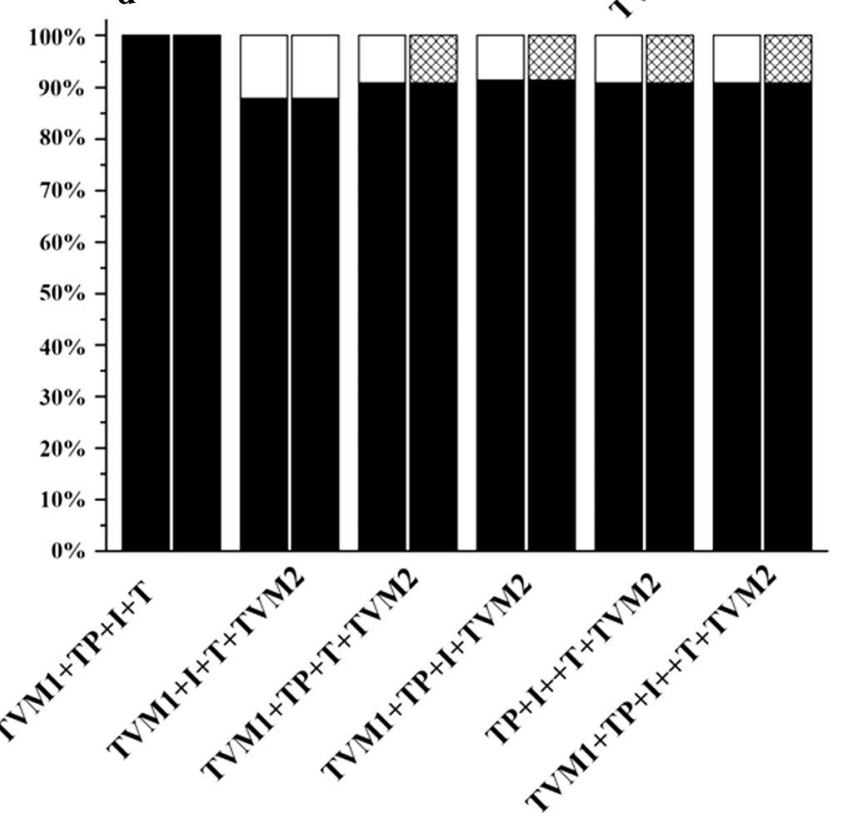

combinations, and $\mathbf{d}$ four-marker combinations and five-marker combinations. I, ITS2; M, matK; T, trnL; TP, trnH-psbA; TVM1, trnVtrnM1; TVM2, trnV-trnM2; TCN, trnC-pet N; TSG, trnS-trnG

wood products. This can require selecting barcodes that are not already considered standard or universal-standard barcode loci developed in living tissues are not always recoverable from wood, especially wood in trade. We extracted DNA from long-dead and dried vouchered xylarium wood specimens, and evaluated barcode amplification efficiency and species discrimination power of standard and atypical loci. As single DNA barcodes, both ITS2 and $\operatorname{trn} L$ showed higher discriminant power compared to other loci using either TaxonDNA method or NJ tree methods. The ITS2

the ability to amplify the barcode in commercial wood and 


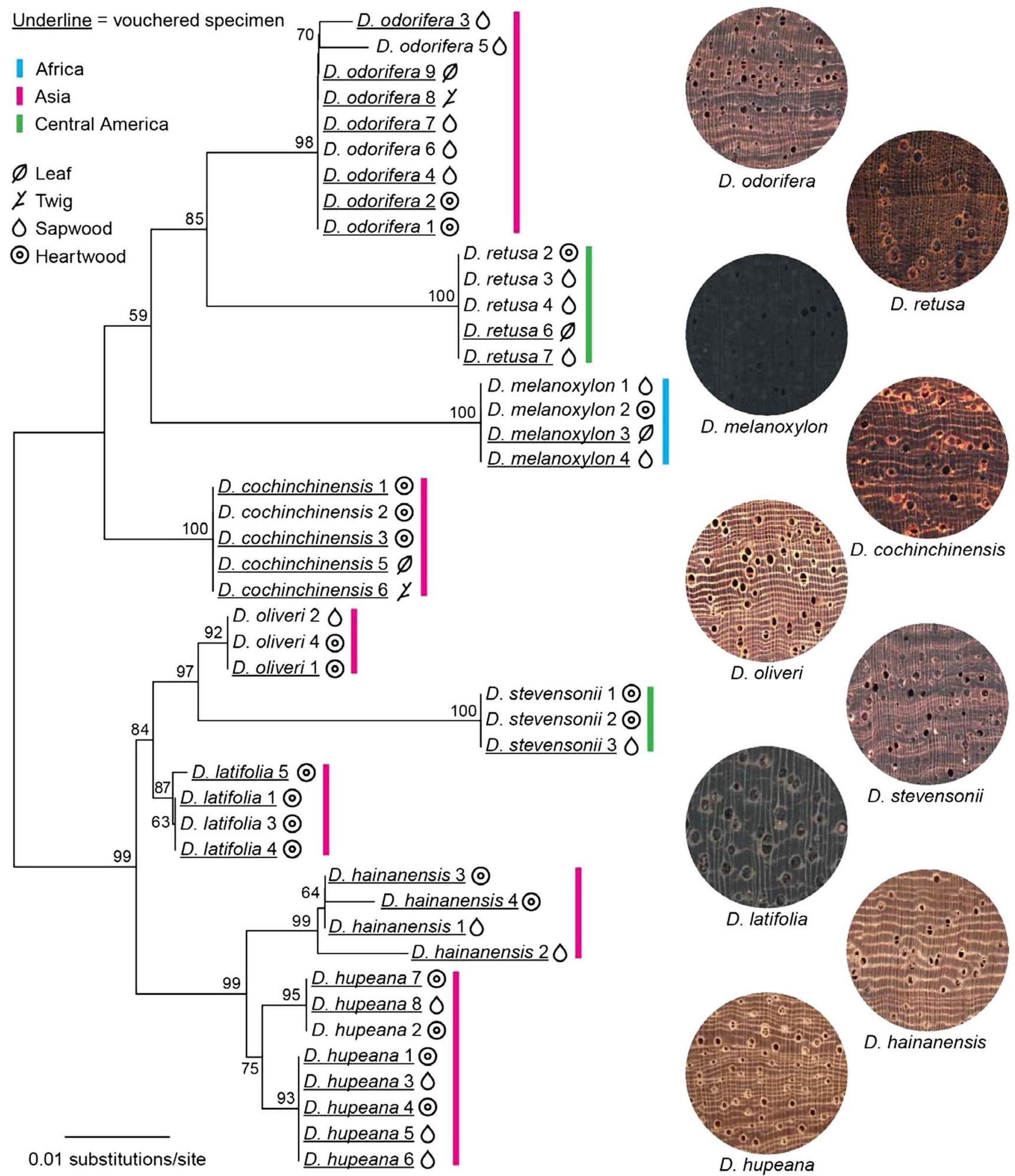

Fig. 2 A taxon identification tree constructed using neighbor-joining analysis of Kimura 2-parameter (K2P) distances showing of the bestperforming two-marker combination ITS $2+t r n H-p s b A$. Bootstrap values $(>50 \%)$ are shown above the relevant branches. D, Dalbergia. Photomacrographs $(\times 16)$ of Dalbergia xylarium taken under stereomicroscope 
region has been proposed as a universal DNA barcode for plant identification in previous studies (Chen et al. 2010; Yao et al. 2010), although there are some known limitations which may restrict its use as universal barcode. The major concerns (Alvarez and Wendel 2003; Besnard et al. 2007; Poczai and Hyvönen 2010; Hollingsworth et al. 2011) could be; (1) incomplete concerted evolution leading to its divergent paralogous copies with an individual, (2) amplification of nonfunctional copies with different evolutionary constraints, and (3) possibilities of contamination by microbial DNA. However, some protocols, i.e., detection of PCR products, BLAST search and analysis of phylogenetic trees were designed to help unravel these problems (Feliner and Rossello 2007). ITS2 region in our study provided the highest number of informative sites (Table 2) and highest correct identification power $(97.5 \%)$ based on the "best close match" test using TaxonDNA (Fig. 1), which was consistent with previous studies (Yao et al. 2010; Han et al. 2013). Therefore, ITS2 remains a highly suitable and powerful region for resolving plant taxonomic and identification issues (Yao et al. 2010). The $t r n L$ region has also shown strong potential as a universal plant DNA barcode (Ribeiro et al. 2011; Hollingsworth et al. 2011; Jiao et al. 2014; Phong et al. 2014), but it exhibits low levels of divergence among closely related species (Taberlet et al. 2007). Our results showed that $\operatorname{trnL}$ was unable to accurately discriminate between the precious timber species $D$. odorifera and the closely related species D. hainanensis based on NJ tree analysis (Supplementary material Fig. S2). Hassold et al. (2016) found that $\operatorname{trn} L$ was not able to provide full species-level resolution among all Malagasy Dalbergia species on selected leaf samples.

The results reported here suggested that single $t r n H-p s b A$ region was insufficient to provide resolution for Dalbergia species, but previous studies relying upon this region in combination with other regions have verified the utility and efficacy for plant DNA barcoding (Newmaster and Subramanyam 2009; Ragupathy et al. 2009; Huang et al. 2015). Additionally, several studies also proposed the noncoding gene trnH-psbA region as a potential plant barcode for closely related species (Cai et al. 2012; Yu et al. 2016). Although $m a t K$ has been proposed as a core barcode for seed plants due to its rapid evolutionary rate and high level of species discrimination in most previous studies (Fazekas et al. 2007; Lahaye et al. 2008; CBOL Plant Working Group 2009), in this work only four of nine species of Dalbergia, were discriminated successfully using the $\mathrm{NJ}$ tree method with $m a t K$. Three noncoding plastid markers, namely, trnV$\operatorname{trnM}, \operatorname{trn} C$-pet $N$, and $\operatorname{trnS}$-trn $G$, have been found to have different species resolution ability within Fabaceae and Vitaceae (Zhang et al. 2009; Ren et al. 2011; Ribeiro et al. 2011). In the present study, the region of $\operatorname{trn} V$-trnM 1 showed higher identification power compared to region of $\operatorname{trn} V$ $\operatorname{trnM} 2$, which has the lowest sequence variation. $\operatorname{trnS}$-trnG showed the lowest success rate of PCR amplification and species identification. Therefore, $\operatorname{trnS}$-trn $G$ could be omitted from barcoding Dalbergia. Our results have clearly demonstrated that DNA barcoding using only a single DNA locus was insufficient to provide resolution for Dalbergia species. These results are similar to previous finding for Aquilaria species (Lee et al. 2016).

\section{Comparison of analytical methods for Dalbergia wood}

With the rapidly increasing availability of DNA sequence data, researchers are developing varied analytical methods to discriminate species, such as tree-based analyses (e.g., NJ tree, maximum-likelihood tree, and maximumparsimony tree), distance-based analyses (TaxonDNA and PWG), machine-learning approaches (BLOG and WEKA), character-based analyses (CAOS), and sequence similaritybased analyses (BLAST) (Little and Stevenson 2007; Frézal and Leblois 2008; Sarkar et al. 2008; Austerlitz et al. 2009; Casiraghi et al. 2010; Alves et al. 2014; Jörger and Schrödl 2014). Previous studies have shown that there are no universal criteria to evaluate the quality of analytical methods for species identification, and different analytical methods often show different species discrimination power on the same data set (Yan et al. 2015). In this study, two widely used methods, i.e., a distance-based analysis (TaxonDNA) and a tree-based analysis ( $\mathrm{NJ}$ tree), were applied to the eight single markers and their possible combinations to evaluate discrimination success of nine Dalbergia species. The different performances of the two methods reflect the different analytical theories of the approaches implemented: TaxonDNA is very simple to use and understand, and has been accepted as a highly workable and accurate method to evaluate barcodes in many studies; in this method, each sequence was queried against the database studied to identify the species associated with its closest match based on the genetic distance (Meier et al. 2006; Bolson et al. 2015; Hartvig et al. 2015). The tree-based approach is a bottom-up clustering algorithm that forms a single tree based on genetic distance matrix (Yang et al. 2017). The fast way to determine the utility of a DNA region as a barcode is to verify whether it can detect species-specific clusters of species using a NJ tree (Bolson et al. 2015).

In this study, the TaxonDNA method provided higher species discrimination power than the NJ tree method, which is in keeping with the results of other studies comparing relative performance of DNA barcoding methods (Austerlitz et al. 2009; Huang et al. 2015). The NJ tree method based on barcode combinations has a few more non-identified and ambiguous results. This might be resulted from the involvement of sequences with relative low success rate of PCR amplification in the combination of DNA sequences. With the increasing diversity of candidate barcode regions and 
growing computational efficiency, exploiting cutting-edge analytical approaches is particularly critical when more traditional methods do not provide sufficient discriminatory power. According to this work, we conclude that the DNA barcoding technique is useful in identifying the species for these nine Dalbergia woods based on both the TaxonDNA method and the $\mathrm{NJ}$ tree method.

\section{Conclusion}

DNA barcodes for wood identification should be short regions with high rates of PCR success because wood has low quantity and quality DNA when compared to most other plant parts. While barcode sequence length can be determined from leaf, cambium, or other plant tissue, amplification success can only be evaluated in wood of the species in question. Because wood and wood products are often traded internationally in dried or processed forms, testing DNA barcoding methods on wood specimens from research xylaria is a way to mimic real-world conditions regarding DNA extraction, quantity, and quality, while taking advantage of the power of xylaria as centralized botanical collections. In this study to discriminate nine species of Dalbergia using eight DNA barcodes singly and in combination, nine combined pairs of loci showed the highest species identification rate based on both the TaxonDNA method and the $\mathrm{NJ}$ tree method. Of those nine, we propose the two-marker combination of ITS2+trnH-psbA as the best combination of DNA barcode to resolve the species we studied. Both ITS2 and $t r n H-p s b A$ are relatively short regions $(<350 \mathrm{bp})$, amplification reactions were performed with high success $(\geq 90 \%)$ using wood as the source material, and this barcode pair showed the highest identification power using both methods of analysis, demonstrating the desirability of building DNA barcoding reference databases for forensic wood identification using xylarium specimens. This study demonstrates how to tap the potential of xylaria for establishing DNA barcoding reference databases for forensic wood identification. In the case of Dalbergia, to realize the full potential DNA barcoding of wood it will be necessary to expand the reference databases to include all potentially commercial species and other look-alike endangered timber species. Such a comprehensive reference dataset can then serve as the foundation for an international wood identification network to combat the increasing illegal exploitation and trade in Dalbergia.

Author contribution statement $\mathrm{YY}, \mathrm{MY}, \mathrm{LJ}$, and XJ conceived and designed research. MY, LJ, JG, and TH performed the laboratory work, MY, LJ, AW, JG and YY analyzed data, MY, LJ, AW, JX, and YY wrote the manuscript. All authors read and approved the final manuscript.
Acknowledgements This work was supported by the China Postdoctoral Science Foundation (Grant no. 2016M590152), the National Natural Science Foundation of China (Grant no. 31600451), the Fundamental Research Funds of Chinese Academy of Forestry (Grant no. CAFYBB2017ZE003), the China Scholarship Council (Grant no. 2016-3035), and U.S. State Department Interagency Agreement (19318814Y0010-140001-0001/P00001).We thank Sarah Friedrich, Department of Botany, University of Wisconsin-Madison for her technical assistance with the phylogram figure.

\section{References}

Alvarez I, Wendel JF (2003) Ribosomal ITS sequences and plant phylogenetic inference. Mol Phylogenet Evol 29(3):417-434

Alves TLS, Chauveau O, Eggers L, Souza-Chies TTD (2014) Species discrimination in Sisyrinchium (Iridaceae): assessment of DNA barcodes in a taxonomically challenging genus. Mol Ecol Resour 14(2):324-335

Austerlitz F, David O, Schaeffer B, Bleakley K, Olteanu M, Leblois R, Veuille M, Laredo C (2009) DNA barcode analysis: a comparison of phylogenetic and statistical classification methods. BMC Bioinformatics 10(14):S10

Baker CS (2008) A truer measure of the market: the molecular ecology of fisheries and wildlife trade. Mol Ecol 17(18):3985-3998

Bergo MCJ, Pastore TCM, Coradin VTR, Wiedenhoeft AC, Braga JWB (2016) NIRS identification of Swietenia macrophylla is robust across specimens from 27 countries. IAWA J 37(3):420-430

Besnard G, Rubio RRd, Vargas P (2007) Plastid and nuclear DNA polymorphism reveals historical processes of isolation and reticulation in the olive tree complex (Olea europaea). J Biogeogr 34(4):736-752

Bhagwat RM, Dholakia BB, Kadoo NY, Balasundaran M, Gupta VS (2015) Two new potential barcodes to discriminate Dalbergia species. PLoS One 10(11):e0142965

Bolson M, Smidt EDC, Brotto ML, Silvapereira V (2015) ITS and trnH-psbA as efficient barcodes to identify threatened commercial woody angiosperms from southern Brazilian Atlantic rainforests. PLoS One 10(12):e0143049

Cai ZM, Zhang YX, Zhang LN, Gao LM, Li DZ (2012) Testing four candidate barcoding markers in temperate woody bamboos (Poaceae: Bambusoideae). J Syst Evol 50(6):527-539

Casiraghi M, Labra M, Ferri E, Galimberti A, De MF (2010) DNA barcoding: a six-question tour to improve users' awareness about the method. Brief Bioinform 11(4):440-453

CBOL Plant Working Group (2009) A DNA barcode for land plants. Proc Natl Acad Sci USA 106(31):12794-12797

Chase MW, Cowan RS, Hollingsworth PM, Berg CVD, Madriñán S, Petersen G, Seberg O, Jørgsensen T, Cameron KM, Carine M (2007) A proposal for a standardised protocol to barcode all land plants. Taxon 56(2):295-299

Chen S, Hui Y, Han J, Chang L, Song J, Shi L, Zhu Y, Ma X, Gao T, Pang X (2010) Validation of the region as a novel DNA barcode for identifying medicinal plant species. PLoS One 5(1):e8613

Cody RB, Dane AJ, Dawson-Andoh B, Adedipe EO, Nkansah K (2012) Rapid classification of White Oak (Quercus alba) and Northern Red Oak (Quercus rubra) by using pyrolysis direct analysis in real time (DART ${ }^{\mathrm{TM}}$ ) and time-of-flight mass spectrometry. J Anal Appl Pyrol 95:134-137

Cowan RS, Chase MW, Kress WJ, Savolainen V (2006) 300,000 species to identify: problems, progress, and prospects in DNA barcoding of land plants. Taxon 55(3):611-616

Degen B, Ward SE, Lemes MR, Navarro C, Cavers S, Sebbenn AM (2013) Verifying the geographic origin of mahogany (Swietenia 
macrophylla King) with DNA-fingerprints. Forensic Sci Int-Gen 7(1):55-62

Deguilloux FM, Petit R (2004) DNA-based control of oak wood geographic origin in the context of the cooperage industry. Ann Forest Sci 61(1):97-104

Eurlings MCM, Lens F, Pakusza C, Peelen T, Wieringa JJ, Gravendeel B (2013) Forensic identification of indian snakeroot (Rauvolfia serpentina Benth. ex Kurz) using DNA barcoding. J Forensic Sci 58(3):822-830

Fazekas AJ, Burgess KS, Kesanakurti PR, Graham SW, Newmaster SG, Husband BC, Percy DM, Hajibabaei M, Barrett SCH (2007) Multiple multilocus DNA barcodes from the plastid genome discriminate plant species equally well. PLoS One 3(7):e2802

Feliner GN, Rossello JA (2007) Better the devil you know? Guidelines for insightful utilization of nrDNA ITS in species-level evolutionary studies in plants. Mol Phylogenet Evol 44(2):911-919

Frézal L, Leblois R (2008) Four years of DNA barcoding: current advances and prospects. Infect Genet Evol 8(5):727-736

Gao LM, Yan LI, Phan LK, Yan LJ, Thomas P, Long KP, Möller M, Li DZ (2017) DNA barcoding of East Asian Amentotaxus (Taxaceae): potential new species and implications for conservation. $\mathrm{J}$ Syst Evol 55(1):16-24

Gathier G, van der Niet T, Peelen T, van Vugt RR, Eurlings MC, Gravendeel B (2013) Forensic identification of CITES protected slimming cactus (Hoodia) using DNA barcoding. J Forensic Sci 58(6):1467-1471

Gismondi A, Rolfo MF, Leonardi D, Rickards O, Canini A (2012) Identification of ancient Olea europaea L. and Cornus mas L. seeds by DNA barcoding. CR Biol 335(7):472-479

Gismondi A, Marco GD, Delorenzo M, Canini A (2015) Upgrade of Castanea sativa (Mill.) genetic resources by sequencing of barcode markers. J Genet 94(3):519-524

Gismondi A, Marco GD, Martini F, Sarti L, Crespan M, MartínezLabarga C, Rickards O, Canini A (2016) Grapevine carpological remains revealed the existence of a Neolithic domesticated Vitis vinifera $\mathrm{L}$. specimen containing ancient DNA partially preserved in modern ecotypes. J Archaeol Sci 69:75-84

Gould BA, León B, Buffen AM, Thompson LG (2010) Evidence of a high-Andean, mid-Holocene plant community: an ancient DNA analysis of glacially preserved remains. Am J Bot 97(9):1579-1584

Hajibabaei M, Singer GAC, Hebert PD, Hickey DA (2007) DNA barcoding: how it complements taxonomy, molecular phylogenetics and population genetics. Trends Genet 23(4):167-172

Han J, Zhu Y, Chen X, Liao B, Yao H, Song J, Chen S, Meng F (2013) The short ITS2 sequence serves as an efficient taxonomic sequence tag in comparison with the full-length ITS. Biomed Res Int 1:741476

Hartvig I, Czako M, Kjær ED, Nielsen LR, Theilade I (2015) The use of DNA barcoding in identification and conservation of rosewood (Dalbergia spp.). PLoS One 10(9):e0138231

Hassold S, Nd LP, Bauert MR, Razafintsalama A, Ramamonjisoa L, Widmer A (2016) DNA barcoding of malagasy rosewoods: towards a molecular identification of CITES-listed Dalbergia species. PLoS One 11(6):e0157881

Hebert PD, Cywinska A, Ball SL (2003) Biological identifications through DNA barcodes. Proc R Soc Lond Ser B Biol Sci 270(1512):313-321

Hollingsworth PM, Forrest LL, Spouge JL, Hajibabaei M, Ratnasingham S, Bank MVD, Chase MW, Cowan RS, Erickson DL (2009) From the cover: a DNA barcode for land plants. Proc Natl Acad Sci USA 106(31):12794-12797

Hollingsworth PM, Graham SW, Little DP (2011) Choosing and using a plant DNA barcode. PLoS One 6(5):e19254

Horacek M, Jakusch M, Krehan H (2009) Control of origin of larch wood: discrimination between European (Austrian) and Siberian origin by stable isotope analysis. Rapid Commun Mass Spectrom 23(23):3688-3692

Huang X, Ci X, Conran JG, Li J (2015) Application of DNA barcodes in Asian tropical trees-a case study from Xishuangbanna nature reserve, southwest China. PLoS One 10(6):e0129295

Ji Y, Ashton L, Pedley SM, Edwards DP, Tang Y, Nakamura A, Kitching R, Dolman PM, Woodcock P, Edwards FA (2013) Reliable, verifiable and efficient monitoring of biodiversity via metabarcoding. Ecol Lett 16(10):1245-1257

Jiao L, Yin Y, Xiao F, Sun Q, Song K, Jiang X (2012) Comparative analysis of two DNA extraction protocols from fresh and dried wood of Cunninghamia lanceolata (Taxodiaceae). IAWA J 33(4):441-456

Jiao L, Yin Y, Cheng Y, Jiang X (2014) DNA barcoding for identification of the endangered species Aquilaria sinensis: comparison of data from heated or aged wood samples. Holzforschung 68(4):487-494

Jiao L, Liu X, Jiang X, Yin Y (2015) Extraction and amplification of DNA from aged and archaeological Populus euphratica wood for species identification. Holzforschung 69(8):925-931

Jörger KM, Schrödl M (2014) How to use CAOS software for taxonomy? A quick guide to extract diagnostic nucleotides or amino acids for species descriptions. Spixiana 37(1):21-26

Kagawa A, Leavitt SW (2010) Stable carbon isotopes of tree rings as a tool to pinpoint the geographic origin of timber. $\mathrm{J}$ Wood Sci 56(3):175-183

Kress WJ, Wurdack KJ, Zimmer EA, Weigt LA, Janzen DH (2005) Use of DNA barcodes to identify flowering plants. Proc Natl Acad Sci USA 102(23):8369-8374

Krüger I, Muhr J, Hartl-Meier C, Schulz C, Borken W (2014) Age determination of coarse woody debris with radiocarbon analysis and dendrochronological cross-dating. Eur J For Res 133(5):931-939

Kumar S, Nei M, Dudley J, Tamura K (2008) MEGA: a biologistcentric software for evolutionary analysis of DNA and protein sequences. Brief Bioinform 9(4):299-306

Lahaye R, van der Bank M, Bogarin D, Warner J, Pupulin F, Gigot G, Maurin O, Duthoit S, Barraclough TG, Savolainen V (2008) DNA barcoding the floras of biodiversity hotspots. Proc Natl Acad Sci USA 105(8):2923-2928

Lee SY, Ng WL, Mahat MN, Nazre M, Mohamed R (2016) DNA barcoding of the endangered Aquilaria (Thymelaeaceae) and its application in species authentication of agarwood products traded in the market. PLoS One 4:e0154631

Little DP, Stevenson DW (2007) A comparison of algorithms for the identification of specimens using DNA barcodes: examples from gymnosperms. Cladistics 23(1):1-21

Lowe AJ, Cross HB (2011) The application of DNA methods to timber tracking and origin verification. IAWA J 32(2):251-262

Lowe AJ, Dormontt EE, Bowie MJ, Degen B, Gardner S, Thomas D, Clarke C, Rimbawanto A, Wiedenhoeft A, Yin Y (2016) Opportunities for improved transparency in the timber trade through scientific verification. Bioscience 66(11):990-998

Lv T, Teng R, Shao Q, Wang H, Zhang W, Li M, Zhang L (2015) DNA barcodes for the identification of Anoectochilus roxburghii and its adulterants. Planta 242(5):1167-1174

Mcclure PJ, Chavarria GD, Espinoza E (2015) Metabolic chemotypes of CITES protected Dalbergia timbers from Africa, Madagascar, and Asia. Rapid Commun Mass Spectrom 29(9):783-788

Meier R, Shiyang K, Vaidya G, Ng PK (2006) DNA barcoding and taxonomy in Diptera: a tale of high intraspecific variability and low identification success. Syst Biol 55(5):715-728

Newmaster SG, Subramanyam R (2009) Testing plant barcoding in a sister species complex of pantropical Acacia (Mimosoideae, Fabaceae). Mol Ecol Resour 9(Suppl. 1):172-180 
Nithaniyal S, Newmaster SG, Ragupathy S, Krishnamoorthy D, Vassou SL, Parani M (2014) DNA barcode authentication of wood samples of threatened and commercial timber trees within the tropical dry evergreen forest of India. PLoS One 9(9):e107669

Ogata T, Yahara S, Hisatsune R, Konishi R, Nohara T (1990) Isoflavan and related compounds from Dalbergia odorifera. Chem Pharma Bull 38:2750-2755

Pang X, Liu C, Shi L, Liu R, Liang D, Li H, Cherny SS, Chen S (2012) Utility of the $t r n H-p s b A$ intergenic spacer region and its combinations as plant DNA barcodes: a meta-analysis. PLoS One 7(11):e48833

Pastore TCM, Braga JWB, Coradin VTR, Okino EYA, Camargos JAA, De Muñiz GIB, Bressan OA, Davrieux F (2011) Near infrared spectroscopy (NIRS) as a potential tool for monitoring trade of similar woods: discrimination of true mahogany, cedar, andiroba, and curupixá. Holzforschung 65(1):73-80

Phong DT, Tang DV, Hien VTT, Ton ND, Hai NV (2014) Nucleotide diversity of a nuclear and four chloroplast DNA regions in rare tropical wood species of Dalbergia in Vietnam: a DNA barcode identifying utility. Asian J Appl Sci 2(2):116-125

Poczai P, Hyvönen J (2010) Nuclear ribosomal spacer regions in plant phylogenetics: problems and prospects. Mol Biol Rep 37(4):1897-1912

Puillandre N, Bouchet P, Boisselier-Dubayle MC, Brisset J, Buge B, Castelin M, Chagnoux S, Christophe T, Corbari L, Lambourdière J (2012) New taxonomy and old collections: integrating DNA barcoding into the collection curation process. Mol Ecol Resour 12(3):396-402

Ragupathy S, Newmaster SG, Murugesan M, Balasubramaniam V (2009) DNA barcoding discriminates a new cryptic grass species revealed in an ethnobotany study by the hill tribes of the Western Ghats in southern India. Mol Ecol Resour 9(Suppl. 1):164-171

Reboredo F (2013) Socio-economic, environmental, and governance impacts of illegal logging. Environ Syst Decis 33(2):295-304

Ren H, Lu LM, Soejima A, Luke Q, Zhang DX, Chen ZD, Wen J (2011) Phylogenetic analysis of the grape family (Vitaceae) based on the noncoding plastid trnC-petN, trnH-psbA, and trnL$F$ sequences. Taxon 60(3):629-637

Ribeiro R, Lemos-Filho J, Ramos A, Lovato M (2011) Phylogeography of the endangered rosewood Dalbergia nigra (Fabaceae): insights into the evolutionary history and conservation of the Brazilian Atlantic Forest. Heredity 106(1):46-57

Santos GU, Callado CH, da Costa Souza M, Costa CG (2013) Wood Anatomy of Myrciaria, Neomitranthes, Plinia and Siphoneugena Species (Myrteae, Myrtaceae). IAWA J 34(3):313-323

Sarkar IN, Planet PJ, Desalle R (2008) CAOS Software for use in character based DNA barcoding. Mol Ecol Resour 8(6):1256-1259

Schroeder H, Cronn R, Yanbaev Y, Jennings T, Mader M, Degen B, Kersten B (2016) Development of molecular markers for determining continental origin of wood from white oaks (Quercus L. sect. Quercus). PLoS One 11(6):e0158221

Taberlet P, Coissac E, Pompanon F, Gielly L, Miquel C, Valentini A, Vermat T, Corthier G, Brochmann C, Willerslev E (2007) Power and limitations of the chloroplast $\operatorname{trnL}$ (UAA) intron for plant DNA barcoding. Nucleic Acids Res 35(3):e14

Tamura K, Peterson D, Peterson N, Stecher G, Nei M, Kumar S (2011) MEGA5: molecular evolutionary genetics analysis using maximum likelihood, evolutionary distance, and maximum parsimony methods. Mol Biol Evol 28(10):2731-2739

Tang X, Zhao G, Ping L (2011) Wood identification with PCR targeting noncoding chloroplast DNA. Plant Mol Biol 77(6):609-617

Tao Y, Wang Y (2010) Bioactive sesquiterpenes isolated from the essential oil of Dalbergia odorifera T. Chen. Fitoterapia 81(5):393-396

The IUCN Red List of Threatened Species Version (2016). https:// www.iucnredlist.org/. Accessed 5 Apr 2017

The Plant List Version 1.1 (2013). http://www.theplantlist.org/. Accessed 5 Apr 2017

Wang W, Weng X, Cheng D (2000) Antioxidant activities of natural phenolic components from Dalbergia odorifera T. Chen. Food Chem 71(1):45-49

Wiedenhoeft A (2014) Curating xylaria. In: Salick J, Konchar K, Nesbitt M (eds) Curating biocultural collections: a handbook. Kew Publishing in Association with Missouri Botanical Garden, UK, pp 127-134

Xu C, Dong W, Shi S, Cheng T, Li C, Liu Y, Wu P, Wu H, Gao P, Zhou $S$ (2015) Accelerating plant DNA barcode reference library construction using herbarium specimens: improved experimental techniques. Mol Ecol Resour 15(6):1366-1374

Yan LJ, Liu J, Möller M, Zhang L, Zhang XM, Li DZ, Gao LM (2015) DNA barcoding of Rhododendron (Ericaceae), the largest Chinese plant genus in biodiversity hotspots of the Himalaya-Hengduan Mountains. Mol Ecol Resour 15(4):932-944

Yang J, Vázquez L, Chen X, Li H, Zhang H, Liu Z, Zhao G (2017) Development of chloroplast and nuclear DNA markers for Chinese Oaks (Quercus Subgenus Quercus) and assessment of their utility as DNA barcodes. Fronti Plant Sci 8:816

Yao H, Song J, Liu C, Luo K, Han J, Li Y, Pang X, Xu H, Zhu Y, Xiao $P$ (2010) Use of ITS2 region as the universal DNA barcode for plants and animals. PLoS One 5(10):e13102

Yu M, Liu K, Zhou L, Zhao L, Liu S (2016) Testing three proposed DNA barcodes for the wood identification of Dalbergia odorifera T. Chen and Dalbergia tonkinensis Prain. Holzforschung 70(2):127-136

Zemlak TS, Ward RD, Connell AD, Holmes BH, Hebert PD (2009) DNA barcoding reveals overlooked marine fishes. Mol Ecol Resour 9(s1):237-242

Zhang M, Fritsch PW, Cruz BC (2009) Phylogeny of Caragana (Fabaceae) based on DNA sequence data from $r b c L, t r n S-t r n G$, and ITS. Mol Phylogenet Evol 50(3):547-559

Zhang ZL, Song MF, Guan YH, Li HT, Niu YF, Zhang LX, Ma XJ (2015) DNA barcoding in medicinal plants: testing the potential of a proposed barcoding marker for identification of Uncaria species from China. Biochem Syst Ecol 60:8-14 